P2065

\title{
ベンゼンの代謝物である尿中 $\mathrm{t}-\mathrm{t}-$ ムコン酸に影響を与える 因子の検討
}

西埜植 規秀 ${ }^{1}$ 、坂本 史彦 ${ }^{1} 、$ 城山 康 ${ }^{1}$ 、小笠原 孝敏 ${ }^{1} 、$ 本迫 郷宏 ${ }^{1}$ 、 藤尾 智紀 ${ }^{1} 、$ 宮上 浩史 ${ }^{1}$ 、福田 昌宏 ${ }^{1}$ 、山田 誠二 ${ }^{1}$

${ }^{1}$ 松下産業衞生科学センター

【目的】特定化学物質であるベンゼンの代謝物として、尿中 t-t-ムコン酸を生物学的モニタリングとして利用 する方法がある。作業による懪露以外で尿中 t-t-ムコン酸が上昇していると推測される作業者を認めたため、 薬剂及び食生活の中で同值を変動させる因子について検討した。

【方法】被験者に informed consent を行い、影響すると思われる因子として以下の薬刜等を負荷した。

(1) $\mathrm{H}_{1}$-blocker フマル酸エメダスチン 1 錠 $2 \mathrm{mg}$ を 12 名(内喫煙者 6 名;平均年㱓 41.9 歳)、

(2)他の抗アレルギー剤として、オキサトミド 1 錠 $30 \mathrm{mg}$ を 7 名(内喫煙者 2 名;平均年齢 35.9 歳)、

(3)食生活上での影響を調べるため、ベンゼン環を有する必須アミノ酸で栄養補助剤として市販されているト

リプトファン 1 錠 $50 \mathrm{mg}$ を 11 名(内喫煙者 5 名;平均年齢 37.4 歳)に服用させた。

以上(1)〜(3)の錠剤を負荷した後、t-t-ムコン酸の尿中排出状況を経時的に測定した。尿は内服直前を対照值(C) とし、(服用後) $10 \mathrm{~h}(1), 14 \mathrm{~h}(2), 19 \mathrm{~h}(3), 34 \mathrm{~h}(4), 38 \mathrm{~h}(5), 43 \mathrm{~h}(6)$ の計 7 回採尿した。尿中の t-t-ムコン酸濃度を GC/MS で測定し、クレアチニン補正(ug/g creatinine)した。

【結果】 結果を以下の図に示した。

(1)フマル酸エメダスチンの負荷では、3 名(症例 A,B,C)で異常高值(3017，1426，1092)を認めた。

他の被験者では、ACGIH の基準值を超えることはなかった。

(2)他の薬剤等の負荷では、すべての被験者で大きな変動はなく、異常高值を示さなかった。

[考察]フマル酸エメダスチンの負荷において，異常高值を示した 3 名はすべて鄙煙習慣を持っていた。喫 煙習慣やソルビトールの摄取により、尿中 $\mathrm{t}-\mathrm{t}-$ ムコン酸が上昇するとの報告もあるが、今回の負荷実験の対 照值では喫煙習慣の有無による有意差は認められなかった。しかし、喫煙習慣があるもので負荷後に異常値 を示すものを認めたため、今後も喫煙との関係については検討する必要がある。以上より、ベンゼンの代謝 物として尿中 $\mathrm{t}-\mathrm{t}-$ ムコン酸を用いる際、喫煙者でフマル酸エメダスチンを服用している場合には注意が必要 であることが示唆された。

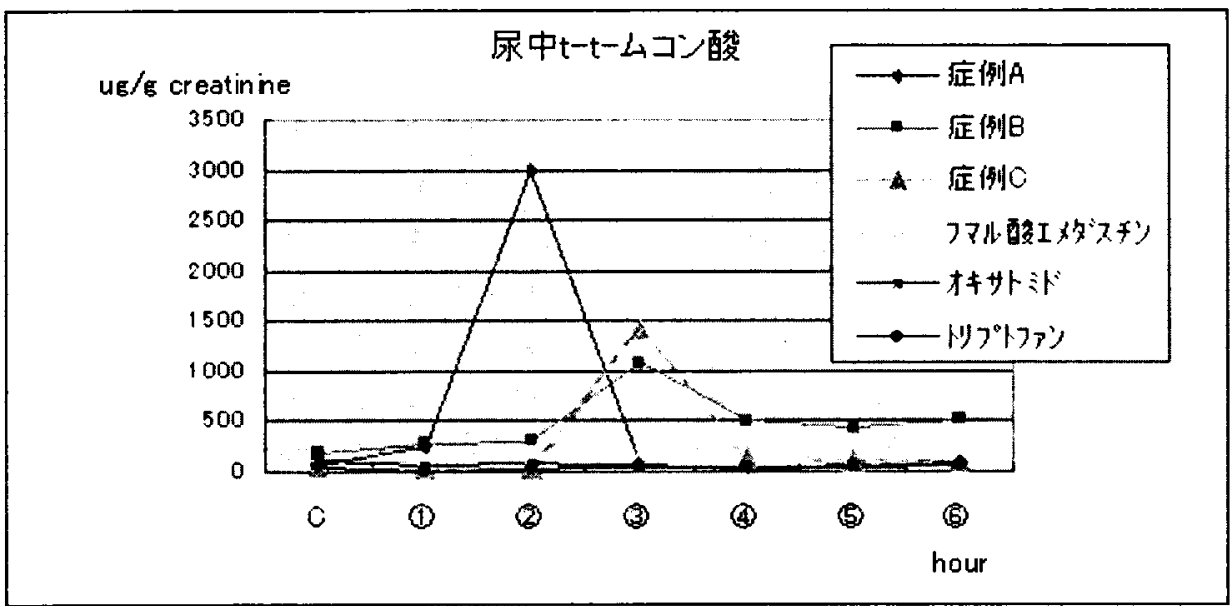

